\title{
The construction of Estonian national style under Soviet rule
}

\author{
Triin Jerlei / University of Brighton / Brighton / UK
}

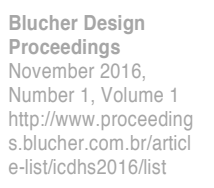

\begin{abstract}
When observing the commodities produced in the Soviet Union, one notices frequent references to pre-Soviet national culture. Estonia was no exception, demonstrating the emergence of a national style that existed in full accordance with the official Communist power. This style was created mostly through the use of visual references to pre-Soviet Estonian culture. Besides imagery, in some cases national references also included partial adopting of certain material practices. This paper focuses on the creation of Estonian national style under the Soviet power to determine its ideological roots and the strategies of imposing and materializing this construct.
\end{abstract}

\section{Keywords}

Soviet Union, national identity, Estonia, industrial design, socialism

\section{Introduction}

This research aims to research the references to pre-Soviet culture in Soviet Estonian design and how during the 1960 s these references were employed to construct a national style, in order to determine the ideological roots and strategies of imposing and materializing this construct. To better understand the different motivations behind this construction, this study focuses on three different groups individually: The Communist Party, designers and other agents in production process and the consumers. While these construction processes differed throughout Soviet Union according to historical, cultural and political conditions, this research offers an insight into one specific design system. Through this case study, this article both arrives to a better understanding of national propaganda in the multinational Soviet context and proposes a methodological viewpoint for analyzing national style in industrial design.

As mentioned above, the key groups whose interests shaped the construction process of Estonian national style in the discipline of industrial design, are identified as Communist Party, production agents and consumers. This systematization is naturally a simplification: Communist Party includes both the influences of doctrines and texts as the decisions made by party officials in Estonia and in Moscow. Production agents are identified as industrial designers, but also other factory officials and, to some extent, also factory workers insomuch they happened to steer the production process at any stage. Finally, consumers are not only members of the general public, but also design critics, historians and curators. It is necessary to emphasize that naturally these groups should not be seen as completely opposing and homogeneous. Many individuals simultaneously belonged to several categories and, as members of each group varied according to age, gender, education and other factors, their views on national style and its position in Soviet Estonian design differed as well. Nonetheless, this paper still aims to analyze the broad tendencies in view of each category.

Time period in question, 1960s, was crucial in local context as by this period Soviet Estonian economy had reached the capacity to produce and distribute a larger variety of commodities for the general consumer. Having been independent since the fall of Russian Empire in 1918, Estonia and other Baltic States were occupied by the Soviet Union in 1940, unlike the other states that had been under the Soviet rule since 1922. In the post-war period, factories had not yet reached their prewar capacity in quality or quantity and thus the variety and quality of consumer products were not yet sufficient to draw any conclusions concerning style. In 1962, VNIITE, the All-Union Scientific Research Institute for Technical Aesthetics, was founded - a research institute that aimed to propagate contemporary design ideas and to improve the aesthetic quality of Soviet industrial design (Azrikan 1999: 48-50). The establishing of VNIITE is often seen as the beginning of an official industrial design discourse in Soviet context. 


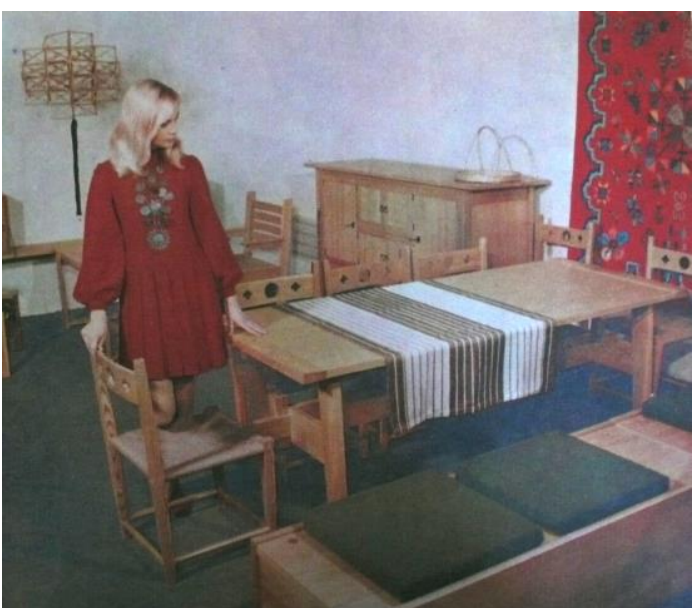

Fig. 1: Furniture set "Estonia", produced by Standard, designed by Bruno Tomberg in 1960s. Credits: Estonian Museum of Applied Arts and Design

\section{Manifestations}

The national symbols used in design mainly referred to preSoviet peasant culture, thus establishing a type of a canon. While 1960s were the height of popularity in establishing the national style in Soviet Estonian design, this use of peasant culture was not a novel concept. In fact, already at the beginning of $20^{\text {th }}$ century peasant culture had been adopted in architecture and interior design, although the scope was not comparable to the industrial design of 1960s. Estonian art nouveau architecture in particular had focused on use of national romanticism, much like the contemporaneous style in Finland. (Kodres 2001: 187) Therefore, national symbolism in industrial design actually referred to two separate époques simultaneously: the mythical peasant culture of the previous centuries and the more accessible brief pre-Soviet independence. This fact can be seen as pivotal in the preference of national symbols.

While Western Communism was, in its nature, against nation-states and nationalism, Soviet Union was actively employing nationalism in the interest of Socialist propaganda. National references were actively used in Soviet propaganda already since the very beginning of the regime. Lenin had already emphasized every nation's right to self-determination (Lenin 1914: 227). Later, during Stalin's reign, nationalism became a weapon for constructing both local and all-Union narratives in the interest of propaganda. As pointed out by Victor Margolin in his study on the Stalinist propaganda magazine USSR in Construction, one of the main reasons behind adopting national references in Soviet propaganda was a wish to convey an image of a future embracing all diverse ethnic and national groups (Margolin 1997: 167). The same traditions were prevalent not only in Estonia, but elsewhere in USSR as well. Greg Castillo has written on the subject of Soviet Orientalism that while the calculated use of regional traditions ended with Stalinism, national references emerged since the 1960s in new ways, bordering on kitsch (Castillo 1997: 33).

In her research of Soviet fashion, Djurdja Bartlett has argued that propagation of national symbols in Soviet design acted as an ideological barrier against Western trends. (Bartlett 2009: 230). This idea can also be seen as a pivotal factor in Soviet Estonian industrial design. As already mentioned, the discipline was still new during the period in question, the 1960s. Thus, for local public national style was supposed to reduce the power of international trends and to stop Western design from becoming a leading example. However, this objective was doomed from the very beginning. Especially in European areas of Soviet Union, West soon became the "framework of universal categories", as phrased by Piotr Piotrowski (Piotrowski 2009: 28). Even certain Soviet design institutions, most notably VNIITE, started propagating Western values and standards in design (Azrikan 1999: 64). A small number of designers, for example a renowned design professor Bruno Tomberg, introduced national references to mass production during the 1960s, but as the style became popular amongst the general public, it was soon disregarded as kitsch and avoided by designers. Thus, national style never became the prevalent style in the realm of Soviet Estonian consumer goods; however, it persisted in small details and certain products, causing art critics headache for years to come.

One of the key symbols was the national dress, the patterns of which were used not only in textiles, but also on other types of products. Katrin Kivimaa has studied the manifestations of national identity in the visual arts. She notes in her study of feminine identity that folk costume played the same symbolic role in national identity during the national movement of the $19^{\text {th }}$ and early $20^{\text {th }}$ centuries. (Kivimaa 2009: 137) She states further: "Thus, folk costumes had already become a conventional and formal sign of ethnos, which the Socialist Realist model adopted." (Kivimaa 2009: 135) Mostly, symbols referred to various parts of the female costume. One of the most popular uses of national costume was a small wooden doll in national costume, produced by Salvo. The appearance of different dolls varied greatly, but they were always in production throughout the entire Soviet period. Use of national

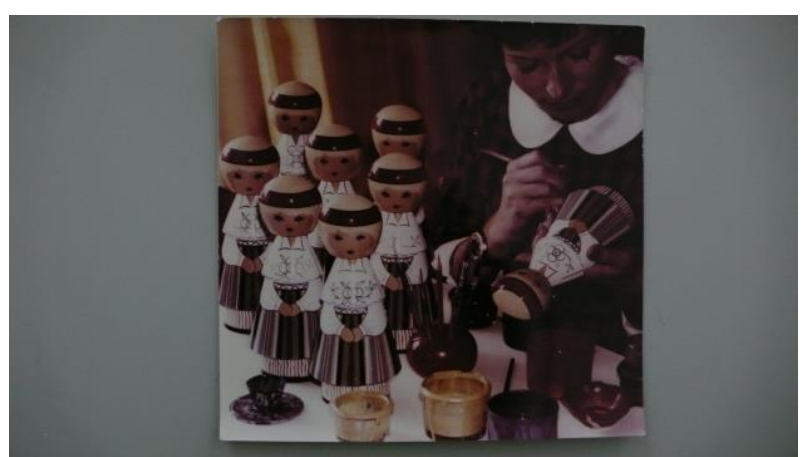

Fig. 2: Factory Salvo. Late 1970s or 1980s. Credits: Estonian Museum of Applied Arts and Design 
dress in Soviet propaganda was not specific to only Estonia, but rather a common method for referencing pre-Soviet traditions and culture. Evidence suggests that this type of doll in a national costume was fairly common throughout the Socialist Bloc as means for demonstrating an idea of a national identity: for example, Vladimir Kulic the Yugoslavian pavilion of EXPO '58 as being filled with "forty-five dolls dressed in traditional folk attire from all parts of Yugoslavia, surrounded by the images of the country's most beautiful natural landscapes. " (Kulic 2012: 161).

Besides national dress, other peasant images were used as well, although to a lesser extent. One curious example is a souvenir spinning wheel produced by Salvo in 1965. In itself, it was an interesting example of emphasising the image of traditional culture, while neglecting the actual content. Initially, a spinning wheel had been a tool, not a decorative object. In 1965, very few households would have used a spinning wheel for its original purpose, especially as the Soviet power insisted collectivisation. As such, while this object was based on traditional ways of life, it was also an active attempt to reduce rural culture to decoration. While at first glance it could have been seen as an apologetic revival of the past, the souvenir spinning wheel was rather a final blow to peasant life, suggesting that its rightful state was a novelty item. This object only features in one product catalogue in 1965, and was therefore probably produced only in small quantities. However, it was definitely not a sole example of revivalism of traditional ways of life. Even in the 1980s, Tartu Plastics Factory was producing a small weaving loom, usable for making doll carpets.

Another popular symbol of national revivalism in design, especially on souvenirs, was medieval architecture in Tallinn. While the Baltic-German roots of Estonian culture were otherwise denied or devalued, using the Old Town as a symbol was a good example of how some aspects of it were appropriated. As Tallinn was one of

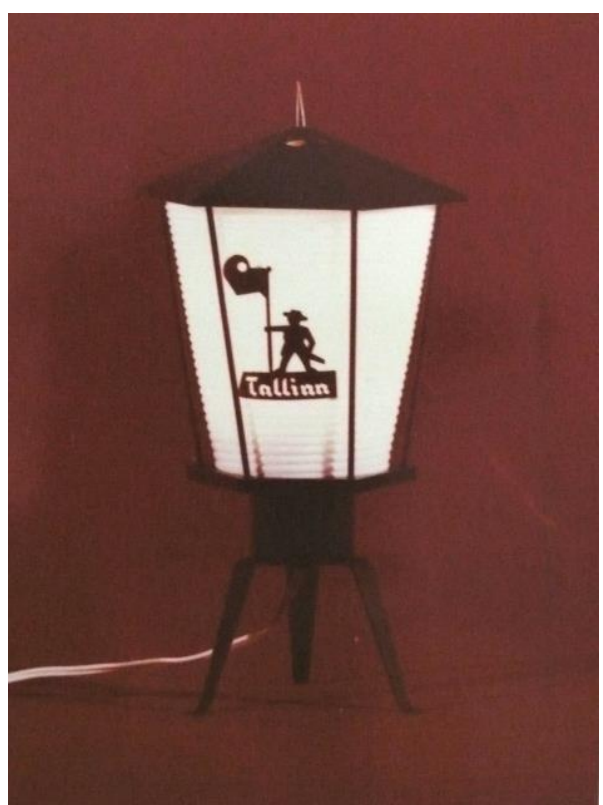

Fig. 3: Lamp "Old Thomas”. Designed by Bruno Vesterberg and produced by Estoplast. In production from late 1960s until early 1980s. Credits: Estonian Museum of Applied Arts and Design. the few cities with an old town built according to Western traditions, either the town silhouette or images of single medieval buildings were used because of their distinguishability. One interesting example of using the Old Town as a source of inspiration for a product was the lamp "Old Thomas", designed by Bruno Vesterberg in late 1960s and produced until the early 1980s. It was shaped like an old-fashioned lantern and decorated with a figure of Old Thomas, famous from the weathervane of the Tallinn Town Hall. The lamp was produced in large quantities and became popular both in Estonia and amongst tourists. During this period of establishing the national design tendencies in the 1960s, stylistic strategies were not the only tool for conveying the romanticism of national ideas in mass production. Besides purely visual references, souvenir industry also employed different production methods for ideological aims. In 1966, Uku was founded - an association that employed non-professional craftspeople (Uuemõis 1975: 2). It was a peculiar example of using nationalist material practices for official ideology. Employees were able to work from home and make national souvenirs according to designs by professional artists. Traditional national handicraft in Uku's example was used as an ideological symbol of national traditions in general. Different technologies, from metal- and woodwork to embroidery were used in production. However, while in traditional handicraft one person would make an entire object from scratch, in Uku the work was divided into stages, all of which were carried out by different people. While on paper Uku's aim was 'keeping traditional handicrafts alive', it was still rather a step towards mass production, except that the factory system existed only as a work arrangement, not as an actual physical building. Therefore, while Uku used national connotations to create an illusion of maintaining traditional ways of life, it was a compromise between the factory setting and a traditional work environment.

These examples raise a question: how exactly did these national references emerge? Returning to the three focus groups, how exactly did each of them function in the development of this style? The use of peasant culture in crafts and industrial design in post-Stalinist era has been documented in other Socialist countries as well, for example by David Crowley in Poland (Crowley 1994: 195). However, the manifestations of national imagery differ in countries due to variations in political structures and local industrial design. Analyzing the illustrating examples, most of them are found in the realm of mass production, which was fairly typical to national elements. There were some highly respected designers who employed references to traditional peasant culture in exhibition 
objects, but only during a brief period at the beginning of the period in question. Soon, as national imagery was gaining popularity with the general public, many art and design critics stood against it as a sign of the decline in aesthetic taste, as this article will demonstrate below.

In an article published as early as 1969, renowned Estonian art historian Leo Gens wrote: "The dissociation in material environment has become a discerning feature of contemporary culture. Man really needs romance, needs a so-called carnival situation, it is not a coincidence that we have so many replica windmills, almost genuine country taverns with pseudo-national food and pseudo-national interiors. [...] If the attic is empty, these needs are satisfied with wooden candlesticks by 'Uku', baskets, small tankards or national dolls by 'Salvo'”. (Gens 1969: 2)

In Gens's view, mass-produced national objects were a poor substitute to genuine folk artefacts that were used to escape from reality. As the contemporaneous Soviet interiors and objects were usually deliberately simple and lacked decoration, people tended towards the opposite. Folk objects or their contemporaneous mass-produced counterparts were familiar, easily recognizable and sentimental. This type of critique from renowned critics, combined with the evolution of contemporaneous design ideologies and an expanding knowledge of global design theories, was arguably an important factor for the decrease in interest towards national tendencies amongst more renowned industrial designers. Later, Western influences became more prevalent in the works of more informed designers.

Meanwhile, Gens's critique illustrates another viewpoint. When it comes to consumers, it should be stressed that, comparing the design structures present in Soviet Estonia and Soviet Union in general to those functioning in Western Europe and the United States at the same time, consumers had significantly less power in determining the style and typology of products. In a state economy there was little competition between different factories and without financial profits factories and designers had no incentive to take the views of consumers into consideration. Additionally, it is extremely problematic to study the opinions of consumers due to censorship in Soviet media. The only testimonies that remain from Soviet consumers in regards to the contemporary views towards national style are reader's letters from newspapers. These are not necessarily authentic, as newspapers were controlled by the Communist party. Therefore, this critique also acts as evidence to the popularity of neotraditionalist design. Although consumers might not have played a significant role in encouraging national references, they definitely welcomed the new style.

Therefore, having analyzed the small role played by consumers and the reluctance of designers and other design specialists, this paper reaches the conclusion that the main initiator of neotraditionalist symbolics was the Soviet power. The prevalence of this style in mass-produced design which is submitted to government control to a greater degree than craft, applied arts or exhibition objects demonstrates the involvement of Communist power. As the final proof, it is important to stress the openness of discussing political intentions behind the propagation of national style. To no extent should the role held by the state in establishing a certain style in industrial design be seen as a secret intervention happening behind the scene, but rather as a deliberate and open strategy to demonstrate the willingness to improve and alter the existing Soviet reality. In an article published in 1966, the Minister of Local Industry declared the aim of Uku to be the demonstration of scope and perspectives of Estonian national culture to the entire world, disproving claims by some emigrant groups that everything national was doomed in Soviet Estonia. (Uuemõis 1975: 2) Therefore, the scope of national style within industrial design was beneficial in terms of Soviet propaganda, to create an illusion of a national artistic autonomy and of self-determination enjoyed by Estonians in USSR.

\section{Conclusion}

Manifestations of national culture in Soviet Estonian design mostly focused on pre-Soviet peasant culture, although there were also examples of using other recognizable symbols and landmarks. While the establishing of national style in Soviet Estonian industrial design was a joint effort between the state power and the designers, Communist Party played an important part in this process. Although amongst designers and design critics national references soon became a sign of poor taste, these references had several functions within Soviet ideology: to show the Soviet system favorably to the outside world and to reduce the effect of Western design on local production. As at least the second objective was not reached, national references still remained present in certain areas of mass production. 


\section{References}

Azrikan, D. (1999). 'VNIITE, Dinosaur of Totalitarianism or Plato's Academy of Design?', Design Issues, 15(3), pp. 45-77.

Bartlett, D. (2009). Fashioneast: The Spectre That Haunted Socialism. London: MIT Press.

Crowley, D. (1994). 'Building the World Anew: Design in Stalinist and Post-Stalinist Poland', Journal of Design History, 7(3), pp. 187-203.

Gens, L. (1969) 'Inimene, Ese, Keskkond [Human, Artefact, Environment]', Rahva Hääl, 12/10/1969, pp. 2-3. Kivimaa, K. (2009) Rahvuslik ja modernne naiselikkus Eesti kunstis 1850-2000 [National and Modern Femininity in Estonian Art 1850-2000]. Tallinn: Tartu Ülikooli Kirjastus.

Kodres, K. (2001) Ilus Maja, Kaunis Ruum [Charming House, Beautiful Space]. Tallinn: Prisma Prindi Kirjastus.

Kulic, V. (2012) 'An Avant-Garde Architecture for an Avant-Garde Socialism: Yugoslavia at EXPO '58', Journal of Contemporary History, 47(1), pp. 161-184.

Lenin, V. I. (1914) 'The Right of Nations to Self-Determination', in Nations and Identities, ed. Vincent P. Pecora. (2001) Oxford: Blackwell Publishers.

Margolin, V. (1997). The Struggle for Utopia. Rodchenko, Lissitzky, Moholy-Nagy 1917-1946. Chicago, London: The University of Chicago Press.

Piotrowski, P. (2009) In the Shadow of Yalta: Art and the Avant-Garde in Eastern Europe, 1945-1989. London: Reaktion.

Uuemõis, R. (1975). 'Kodutöönduse Organiseerimisest Vabariigis [About Organising Home Industry in the Republic]', Kohalik tööstus: informatsiooniseeria [Local Industry: information series] 9(9), pp. 2-3.

\section{Biographical note}

Triin Jerlei is a doctoral student at University of Brighton. Her research focuses on Soviet design, analyzing the occupation of design within a totalitarian society and the structure of Socialist design economy. Additionally, she has studied Soviet factory glass and its position within a wider Modernist context. 